\title{
O CORPO AMOROSO EM O LIVRO DA PAZ DA MULHER ANGOLANA, AS HEROÍNAS SEM NOME: SUBSÍDIOS PARA LEITURA
}

\author{
THE LOVING BODY IN O LIVRO DA PAZ DA \\ MULHER ANGOLANA, AS HEROÍNAS SEM \\ NOME: A SUPPORT FOR READING
}

Maria Salete Daros de Souza ${ }^{1}$

\section{RESUMO}

Memórias de O livro da paz da mulher angolana, as heroínas sem nome (Kasembe; Chiziane, 2008) embasam a reflexão que este estudo desenvolve a respeito do corpo amoroso das mulheres, por ocasião da Guerra Civil em Angola. Seguindo um percurso de domesticação e de aviltamento do corpo feminino pelas circunstâncias trágicas da guerra - de caráter eminentemente androcêntrico e genderizado -, os corpos dos sujeitos femininos são trazidos à luz da reflexão através de testemunhos de vivências de ultraje, exacerbadas pela propaganda nacionalista da guerra e, em alguns casos, através de memórias de superação e de empoderamento político e social. Neste sentido, este estudo apresenta subsídios para ler o corpo dos sujeitos femininos em diálogo com questões de gênero, de sexualidade, de classe e de raça, cartografado num panorama de gênese histórico-cultural que se complexifica com a problemática da guerra, do colonialismo e do pós-colonialismo.

PALAVRAS-CHAVE: Corpo amoroso; gênero; Guerra Civil angolana. 


\section{ABSTRACT}

Memories of O livro da paz da mulher angolana, as heroinas sem nome (Kasembe; Chiziane, 2008) are the point to the reflection proposed here related to the loving body of women during the civil war in Angola. Considering the problematic of the female body domestication in the tragic circumstances of war - with its androcentric and gendered character - the female subjects and their bodies are brought to reflection. The gendered implication of the nationalist propaganda war and, in some cases, a subsequent political and social female empowerment are also discussed. Thus, this article intends to read the loving body of the female subjects in dialogue with gender, sexuality, class and race, concerning a cultural and historical panorama in a hard universe of war, colonialism and postcolonialism.

KEYWORDS: Loving body; gender; Angolan Civil War.

\section{O LIVRO DA PAZ DA MULHER ANGOLANA, AS HEROÍNAS SEM NOME}

Organizado pelas escritoras Dya Kasembe e Paulina Chiziane (2008), resultante de um projeto coordenado por uma equipe multidisciplinar de dezoito pessoas de três diferentes países: Angola, Moçambique e Noruega, o livro pretende ser uma mensagem de paz.

Com título escolhido coletivamente pelas entrevistadas, as coautoras, o livro é uma homenagem a todas as mulheres angolanas que foram vítimas da Guerra Civil; ${ }^{2}$ é também um gesto de agradecimento a todas as pessoas que ajudaram a compreender a luta, as alegrias e as mágoas da dor da guerra. Sobretudo, é uma tentativa de tirar as mulheres angolanas do silenciamento, partilhando seus sofrimentos "para cimentar o momento de paz" (Kasembe; Chiziane, 2008, p. 191), dando-lhes o estatuto de 'heroínas da paz'.

Financiado pela Ajuda Popular da Noruega, ${ }^{3}$ o projeto do qual o livro resultou foi gestado na Conferência Internacional sobre "Mulheres e participação política e pública”, realizado em Luanda, em 2006, e seguiu um percurso de encontros e de recolha de histórias, cujo processo de encerramento deu-se em junho de 2008, em Luanda, com análise crítica das histórias, definição dos critérios de seleção, da estrutura e do título do livro.

Atribuindo às mulheres angolanas o estatuto de 'heroínas da paz', o livro subverte o desvio de gênero próprio da guerra - universo androcêntrico e militarizado -, sugerindo discussão de episteme assentada no conceito de paz feminista; especialmente sugere questionamento do mérito androcêntrico dos processos de pacificação, historicamente reconhecidos como de exclusiva autoria masculina. 
Mulheres de diferentes estratos sociais de seis províncias de Angola, de idade entre 14 a 80 anos, participaram da pesquisa, revelando dor, sofrimento e bravura, algumas vezes demonstrando consciência política e capacidade de se envolver em projetos de caráter social emancipatório.

A pesquisa publicada pela editora Nzila, em agosto de 2008, contempla um universo total de 95 testemunhos de mulheres. Estruturalmente organizado de forma simples, o livro, além de prefácio e introdução, apresenta provérbios bilíngues ${ }^{4}$ e pequenos poemas de autoras africanas: Alda Lara, Dya Kasembe, Ana Paula Tavares, Alda do Espírito Santo e Lina Magaia, intercalando seus textos aos testemunhos. Como ilhas de reflexão, esses textos/poemas, distribuídos aparentemente de forma aleatória, vindos de fora da pesquisa, mas não de fora do continente africano, reforçam a legitimidade do coro de vozes que ali soa. Também algumas ilustrações, desenhos de autoria das mesmas testemunhas, abrem os depoimentos, representando as vivências relatadas e a memória em movimento.

Ao final, além da conclusão, o livro apresenta bibliografia - assim nomeada, constituída pelos nomes das mulheres testemunhas -, relação de nove entrevistadoras partícipes do projeto, anexos com dados sobre a participação da mulher angolana na política - abrangendo o período de 2000 a 2007 -, e um painel com datas significativas na vida dos angolanos, correspondente aos anos de 1492 (início da dominação portuguesa) a 2002 (4 de abril - assinatura dos Acordos de Paz, fim da Guerra Civil). Por último, um álbum com fotos registrando momentos da pesquisa, como seminários, recolha de testemunhos, recreação cultural, organização do livro, fotos de algumas das mulheres angolanas depoentes, e cenas do cotidiano e do trabalho dessas mulheres, perfazendo, no todo do livro, um total de 247 páginas.

\title{
O CORPO AMOROSO AVILTADO, MAIS QUE DOMESTICADO, DAS MULHERES DE ANGOLA
}

\author{
Já viram olhos de fome? São olhos tristes, desesperados. \\ Se um dia os virem como eu os vi, ficarão marcados e irão \\ lembrar para sempre. \\ Kasembe e Chiziane ${ }^{5}$
}

A construção social do corpo feminino na tradição cultural angolana parece ser, conforme indicam estudos realizados por Dya Kasembe (2011) e Rosa Melo (2007), marcada pela genderização e pela ritualização. São corpos controlados, educados e autorizados para a sexualidade e para a maternidade através de rituais iniciáticos. Pode-se dizer, portanto, deste corpo feminino, que é um corpo socialmente controlado e 'autorizado' para a procriação, para o exercício da maternidade e da educação dos filhos, funções eminentemente da vida privada e da sobrevivência da família. 
Essa 'formação' e a 'tradição', - exceção feita a algumas histórias de vida exemplares do ponto de vista da superação e do empoderamento -, permeiam os testemunhos do livro objeto deste estudo, tendo, primeiramente, o colonialismo e posteriormente as guerras como agravante da genderização das relações pessoais e sociais.

De sorte que, parece haver uma herança cultural de submissão a instituições como o casamento e a família, nas quais as mulheres teriam de cumprir os papéis de esposa incondicional, mãe de prole numerosa e responsável pela economia doméstica. Nessas circunstâncias, ficam minimizadas as questões da sexualidade prazerosa, do afeto, e dos problemas próprios da coabitação, muito embora os estudos aqui anteriormente referidos tendam a defender o caráter da educação para o prazer sexual das jovens.

O colonialismo e as guerras criaram uma realidade totalmente adversa e traumática do ponto de vista das desigualdades sociais e do desrespeito às culturas, sobretudo favorável ao endurecimento das desigualdades de gênero. Cabe trazer para a discussão um dado agravante e discriminatório, tecido nas mentalidades ocidentais, com prejuízo para populações periféricas, do Sul, como Angola: "Historicamente, a África tem sido marcada como um lugar onde o amor não existia (segundo o discurso missionário sobre tráfico de escravos) ou tornou-se impossível em função das condições políticas e econômicas" (Cole apud Bhana, 2013a, p. 100, tradução minha). ${ }^{6}$

Entendimentos desta ordem compactuam com interesses imperialistas, promovendo a subalternidade dos povos 'conquistados', rotulando-os de 'incivilizados', de 'incapazes de amar', desrespeitando seus usos e costumes, atingindo-lhes nos sentimentos identitários e de pertença. Além do que, fizeram agravar diferenças culturais, criando estereótipos e legitimando atitudes a serviço do imperialismo e do patriarcado. Mormente, por ocasião das guerras, exacerbaram-se diferenças de gênero, como procurarei desenvolver, tendo como foco a condição de vida das mulheres e o lugar do corpo feminino. Um corpo que será testemunhado através do aviltamento de sua dignidade, da violência e do desprestígio. Um corpo mais que domesticado, portanto, muitas vezes aviltado, conforme fragmentos de vozes de 'O livro da paz'.

Papéis considerados eminentemente femininos, 'domesticados', foram pelas mulheres desempenhados a serviço da guerra, como ilustra o testemunho abaixo.

Nestes anos todos a libertação incluiu e contou com a participação humilde e sacrificada das mulheres que, na retaguarda geravam e criavam os filhos, cultivavam no campo o sustento da família e providenciavam, também, o apoio aos aquartelamentos e unidades dos combatentes. (Kasembe; Chiziane, 2008, p. 87). 
$\mathrm{Na}$ retaguarda, como refere o testemunho, muitas mulheres excederam a suas funções, e, no anonimato, prestaram também serviços de logística de guerra.

Das circunstâncias da guerra, conforme ressoa do testemunho que segue abaixo, resultaram casamentos que não se sustentaram, 'uniões falhadas', perda da identidade e dos ciclos da vida, ritos do amor e do afeto resgatados temporariamente, em circunstâncias adversas ao pertencimento e às raízes:

Tenho cinco filhos de duas uniões falhadas feitas em tempo de guerra. Durante esse período terrível da nossa história, nós aqui estávamos habituados a vivermos em zig-zag, quer dizer: ora acalmia em que as pessoas viviam a fundo essa acalmia, dançava-se, namorava-se, casava-se e, de repente, tudo desaparecia para vivermos o tempo em que abandonávamos tudo para nos refugiarmos nos catelelens. (Ibid., p. 183).

No movimento brutal da guerra, o corpo que dança e que namora, que se exibe para a conquista, é o mesmo que, repentinamente - sem ciclos estabelecidos -, despe-se de alegrias e de dignidade para esconder-se no refúgio, em defesa da vida.

Nos relatos referentes à vida privada, são recorrentes os depoimentos sobre violência doméstica:

Ele me violenta. Se não encontra comida feita, banho preparado quando chega do mar é 'maca'. Muitas vezes me bate. É um ingrato. Até parece que o valor da mulher é só nascer os filhos. Apesar das falhas nos esforçamos por sermos felizes. Há dias que ele até é bom marido. Só às vezes. (Ibid., p. 31).

No depoimento que segue, as agressões e a indiferença sexual são atribuídas à fome e à guerra:

Naquele tempo de guerra, em casa era pancadaria daqui, pancadaria dali. Quando o marido conseguia o seu dinheiro, ia embora comer na rua, porque achava que em casa eram muitas bocas. Eu quase me separei dele, mana. [...] afinal quando há fome em casa, não há cá marido que dorme com a mulher. O homem não tem força de nada, dorme tipo criança, aquilo é cada um por si, Deus por todos. (Ibid., p. 153).

A recorrência das agressões são confirmadas e analisadas em testemunho:

Aqui temos muita violência doméstica. No momento da dor, as mulheres apresentam o problema às autoridades, mas logo a seguir retiram a queixa. É porque não se podem sustentar, com a guerra, não tiveram oportunidade de se formar. Pensam na importância da família e na união dos filhos e por isso perdoam os esposos e escondem a violência. (Ibid., p. 122).

Há casamentos cujo fim é atribuído ao racismo, e ao desprestígio da mulher que, após ter-se revelado fecunda (um antigo valor cultural), 'domesticada', portanto, é trocada por outra: 
Casei [...] com um branco, que me abandonou por causa do racismo e me deixou uma filha mulata. Voltei a casar-me com um negro e tive mais quatro filhos. Este casamento também acabou, porque este marido preferiu trocar-me por uma prima. [...] Eu fui trocada por dois maridos. (Ibid., p. 25).

A assumida condição de 'ser trocada' denota aceite de condição social desprestigiada, submissão genderizada, colocando-se ao nível de mercadoria.

Na voz que segue, se há um corpo agredido, há, também, um ser mulher que se rebela contra a submissão desejada pelo homem/marido em função de suposta superioridade econômica feminina: "O meu primeiro casamento durou 27 anos. Ele era professor e eu já era comerciante. Eu tinha mais dinheiro que o meu marido e ele me agredia. Não aceitava o meu dinamismo e queria a minha submissão" (Ibid., p. 78).

As fugas, a morte, a orfandade, a destruição das famílias fazem parte do brutal panorama da guerra, resgatado das memórias das mulheres de Angola:

A guerra fez sofrer muita gente, destruiu famílias [...] naquela altura tinha de se fugir à guerra com as trouxas na cabeça, se esconder tipo bicho na mata, é por causa da guerra que primeiro o meu pai morreu na tropa e depois a minha mãe; naquele tempo de fugir lhe apanharam para transportar as coisas que eles roubaram, mas ela não agüentava e lhe deram um tiro. Fiquei órfã. (Ibid., p. 43).

A brutalidade parece recair mais barbaramente sobre as mulheres, penalizadas com a morte por não corresponderem a funções que lhes exigiam, conforme atesta o fragmento de memória acima.

A julgar pelos testemunhos, a subalternidade e discriminação, destinada ao corpo feminino, ancestralmente domesticado e ritualizado, agrava-se na guerra, quando ele é submetido a condições de violência e de aviltamento 'legitimados':

Foi num dos tempos quentes em que fui surpreendida na minha casa. Felizmente pouparam-me a vida, mas a humilhação foi grande, além de levarem tudo o que havia à volta, levaram também o que estava sobre o meu corpo. E como se não bastasse como humilhação, começaram a disputar-se para ver quem levaria a mulata para ser sua. Mas milagre de Deus, uma voz sensata ordenou que partissem e que não me tocassem. (Ibid., p. 183).

A violência, na fala acima, agrega ao gênero a discriminação ao outro, o híbrido/a mulata, uma alteridade desqualificada aos olhos do estrangeiro, duplamente passível, portanto, de desrespeito e de violação.

O sofrimento é de muitos anos e são muitas as obras realizadas por mulheres que entregaram, compulsoriamente, seus corpos ao trabalho escravo em troca de sobrevivência, como se lê na narrativa que segue. 
A estrada asfaltada que vocês conhecem que liga Porto Amboim a Ngunza (Kuanza Sul, Sumbe) foi feita com a participação forçada das mulheres. Nas roças de café na Gabela, aquelas pedras do caminho de ferro foi obra barata feita pelas mulheres, elas carregaram, cozinharam, lavaram, regaram em troca de fubá tulha-munguluta (fubá de milho) seco não tratado, moído muitas vezes com o seu 'sapupu', a espiga completa) peixe seco que cheirava nguano (carapau seco salgado não comerciável por estar em estado avançado de putrefação, cheirando mal), e sardinha que também cheirava nguano. $\mathrm{O}$ nosso sofrimento dura há muito tempo. (Ibid., p. 21).

As memórias são também de raptos, de cativeiros de meninas e de mulheres, violentadas e aviltadas na sua condição humana como comprovam os dois depoimentos que seguem.

As 13 meninas que foram raptadas, as mães vinham, eu aconselhava a não chorar, porque as lágrimas de uma mãe, podem fechar a porta das filhas raptadas. Lágrimas só servem para a morte, mas para pessoas vivas, só fecham os caminhos. Eu aconselhava assim as mães a rezar. (Ibid., p. 64).

Fui raptada durante a guerra, pela primeira vez, quando regressava para casa, vinda da Missão onde estudava, mas foram só 24 horas [...]. Pela segunda vez, encontrava-me interna na Missão dos padres [...]. Permanecemos nesse cativeiro durante 3 anos. (Ibid., p. 105).

Além da violação, um traço de agressão e de deboche à tradição - originário do discurso colonialista e militarizado -, observa-se no relato seguinte, lembrando que, originalmente as mulheres eram privadas de educação formal:

Eu vivia numa aldeia perto de uma missão, onde as meninas da zona se refugiavam para fugir das violações das tropas que andavam à caça das moças 'estudadas', como eles diziam. [...] Para alguns militares, celebrar a independência era apanhar essas 'estudadas' e violar. (Ibid., p. 103).

A sujeição das mulheres à violação, legitimada pelo estatuto androcêntrico da guerra, consta desta memória: "No tempo da guerra, nós mulheres não podíamos vir muito cedo à praça [para o trabalho], porque no caminho os homens nos violavam, tanto civis como militares, você não podia fazer nada, guerra não tem lei, não tens para onde se queixar” (Ibid., p. 84).

Cativeiro, violação, fome, vivência sub-humana, agravada pela própria fisiologia do corpo feminino, constam do testemunho que segue.

Não sei se existe algo pior do que o que eu passei nesse cativeiro. [...] Não tínhamos o mínimo de higiene, e no período menstrual, não possuíamos nada para nos resguardar: nem pensos nem panos, nem folhas. [...] a falta total de alimento, fazia com que comêssemos terra, como único alimento. Foi nesse cativeiro que aprendi a dormir em cima de uma árvore. Tinha de ser assim se não quisesse ser violada por soldados... (Ibid., p. 105). 
Para melhor compreender as implicações da maternidade na perspectiva do corpo amoroso aviltado, tendo em vista a propaganda nacionalista de guerra, ${ }^{7}$ há que retomar a questão e examiná-la mais detalhadamente.

Nos nacionalismos as mulheres aparecem num papel metafórico ou simbólico. Sendo que a elas é negada qualquer relação direta com a atuação nacional, pode-se dizer, lembrando McClintock (2010, p. 522) que "O nacionalismo é, assim, constituído desde o começo como um discurso de gênero", e que "Um paradoxo habita o centro da maior parte das narrativas nacionais". As nações ${ }^{8}$ são frequentemente expressas pela iconografia do espaço doméstico e familiar. No entanto, com a figura metafórica da família surgiu, historicamente, um paradoxo: como metáfora a família oferecia uma única gênese narrativa para a história das nações, como instituição foi esvaziada de história e excluída do poder nacional. Relação equivalente pode-se atribuir, por exemplo, à cidadania das mulheres que foram, na Europa pós-Revolução Francesa, indiretamente incorporadas ao Estado-nação, tendo sido reconhecidas cidadãs através dos homens; no direito privado e no direito público eram membros dependentes da família (Kasembe; Chiziane, 2008, p. 523-524).

De sorte que o testemunho: "Marchamos com os nossos filhos nas costas. Fizemos a revolução assim mesmo. Nas costas a criança e no ombro a arma. As armas nos ombros das mães foram os primeiros objectos que os nossos filhos tocaram" (Ibid., p. 95) ilustra o convencimento è adesão das mulheres à causa nacionalista. Por outro lado, mostra-se incompatível com outras vozes de 'O livro da paz', que denunciam direitos negados às mulheres combatentes no pós-guerra. ${ }^{9}$

É, também, valendo-se do expediente do capital simbólico (metafórico) de 'símbolo da nação' que o 'inimigo' utiliza as mulheres e as mães como armas de guerra, procurando, através delas, atingir a nação. Os discursos e as ações de gênero nos nacionalismos de guerra servem, portanto, supostamente, para o bem e claramente para o mal.

A realidade das 'mães da revolução' é, portanto, complexa e brutal, saída do anonimato em raras publicações como as do livro objeto deste trabalho:

As grávidas já sabiam. Quando a barriga é grande, no tempo da fuga tem de andar sozinha. Bastava aquela arma pesada disparar, às vezes o bebê sai antes da hora, por causa do susto da mãe. Ela tinha que andar sozinha, porque o bebê podia nascer a qualquer momento. (Ibid., p. 60).

As 'mães da revolução' ou as' camaradas de armas' são representações ambivalentes, como diz Margarida Paredes (2014, p. 205), que "ligam a maternidade à guerrilha e ao militarismo como se fossem complementares”, e não têm reconhecimento preservado no pós-revolução: 
Enquanto estávamos na guerrilha éramos todas iguais e éramos úteis. Hoje, os meus antigos subordinados passam por mim em bons carros, realizados, apenas porque são homens. Eu vendo aqui no mercado da esquina e nem tenho o suficiente para sustentar os meus filhos. [...] Nas negociações de paz, nós mulheres combatentes fomos esquecidas. (Kasembe; Chiziane, 2008, p. 140).

As 'camaradas de guerra' civis ou militares não só constituem, como trazem consigo outras 'armas de guerra, ${ }^{10}$ alvos fáceis de serem atingidos: as crianças e a fome:

Dói muito ser mãe em tempos de guerra. Ficávamos muitos dias escondidos nos capins. Quando os movimentos de guerra abrandavam, nós as mães, corríamos para as lavras para conseguir algum alimento. Foi nessas ocasiões que muitas mulheres perdiam a vida, eram raptadas ou pisavam minas. (Ibid., p. 60).

Observe-se que o depoimento é uma voz coletiva: 'nós as mães', dando conta de uma realidade de grupo socialmente instituída - a família -, e destituída pela guerra. Desta problemática faz parte, por extensão, uma conjuntura de armas de guerra: a fome, as crianças, o rapto de mulheres e as minas.

Assim é que os testemunhos das mulheres de 'O livro da paz', vindos do outro lado da 'economia de guerra', resgatam memórias da infância e de mutilações do corpo feminino, das quais passarei a ocupar-me.

O testemunho seguinte resgata o nascimento de uma criança no capim, sob um céu aberto de pólvora: "Sou filha da guerra. Quando nasci a guerra tinha 12 anos. Nasci no capim como muitas crianças do meu tempo. Aqui me chamam Cangila, nome que dão a todos os que nascem no caminho ou no céu aberto de pólvora" (Ibid., p. 85).

$\mathrm{Na}$ memória do tempo de criança, era proibido brincar:

A minha cabeça está cheia de imagens do meu tempo de criança. Era proibido brincar. Não se podia ir longe. Minha avó não me deixava nem entrar na mata, subir uma árvore e apanhar uma fruta, mesmo que tivesse fome. Dizia para não pisar qualquer lugar por causa das minas. (Ibid., p. 85).

O trauma coexiste com a memória da escola do tempo de criança:

As notícias da guerra roubavam nossa atenção [na escola]: a colega de carteira, que morreu no ataque da noite, o professor da outra sala que fora raptado [...]. Até hoje eu não gosto de dormir, porque no sono, aquelas coisas antigas voltam a aparecer. (Ibid., p. 85-86).

A banalização da morte também é constitutiva da realidade da infância, na guerra: "Muitas crianças tiveram que enterrar nacos de carne dos próprios pais, mães e irmãos, como quem enterra gatos mortos. Sem lágrimas" (Ibid., p. 124). 
Os corpos de mulheres, mutilados, são recorrentes nos registros de memórias:

Perdi os meus membros em 1985, quando fui com a mãe e a minha irmã à lavra procurar qualquer coisa para comer. $\mathrm{Na}$ altura eu tinha 12 anos de idade. Aconteceu quando trazia a minha irmã nas costas, assustei, já não vi mais nada. Quando acordei, só vi as feridas, não tinha mais pernas e não tinha o braço direito. (Ibid., p. 179).

As minas, como já referido, foram 'armas de guerra' de certo modo pensadas para atingir majoritariamente as mulheres, levando em consideração as lavras - onde foram colocadas -, espaços eminentemente domésticos e de sobrevivência familiar, em Angola trabalhados tradicionalmente por mulheres:

[...] fui amputada da perna esquerda [...] Nos avisaram que tinha lá minas naquela montanha [...] mas por causa da necessidade com as dificuldades de pôr comida na mesa, essa é que nos obrigava mesmo a arriscar mesmo a vida para conseguir mantimentos para sustentar a família [...]. (Ibid., p. 185).

O testemunho seguinte é fragmento de uma trágica história de guerra que soma morte do pai, assassinato da mãe, orfandade e mutilação física:

[...] é por causa da guerra que primeiro o meu pai morreu na tropa e depois a minha mãe [...]. Fiquei órfã. A outra coisa que me dói é a mina que me triou a perna. Accionei uma mina no quintal da minha própria casa. No bairro Calongueri. Como, antigamente, esta casa era usada pelas forças militares, acredito que foram eles que enterraram ali essa mina. (Ibid., p. 43).

Portanto, na esfera do corpo domesticado, própria do gênero e próxima do amor, estou seguindo um fio histórico-cultural, em Angola, que levou ao estado de exceção - lembrando Agamben (2004) -, ao aviltamento e à solidão dos sujeitos femininos, a exemplo do testemunho abaixo.

A mulher em tempo de guerra é desprotegida. Vive abandonada. É ela sozinha com o seu Deus. O marido tem de fugir mesmo porque entre o homem e a mulher, o homem morre primeiro. Mesmo que ele queira ficar nós o protegemos expulsando-o para salvá-lo (Kasembe; Chiziane, 2008, p. 61-62).

\section{O AMOR FENECE}

A solidão, a separação e o aviltamento são impeditivos da vida sexual e do amor entre os casais, em circunstâncias de guerra, conforme o testemunho anteriormente citado: “[...] quando há fome em casa, não há cá marido que dorme com a mulher. O homem não tem força para nada, dorme tipo criança, aquilo é cada um por si, Deus por todos (Ibid., p. 153). ${ }^{11}$ 
Um outro depoimento de mulher, emprestado da pesquisa de $\mathrm{Pa}$ redes (2014, p. 109), faz coro à temática do distanciamento dos casais na guerra, revelando que no aviltamento os corpos se distanciam e o amor fenece:

Na guerra, por causa da fome a menstruação desaparece. A mulher nem faz filho. Os homens que tinham mulheres nem conseguiam dormir com sua mulher. Vai fazer sexo com uma mulher que tá cheia de fome, o marido também tá cheio de fome, os piolhos caíam por aqui [mostra no rosto], só sujidade?

Das relações amorosas, afetivas, familiares, da vida, enfim, faz parte também a morte. Em contexto de guerra tudo se exacerba, invertem-se os papéis e a morte, na maioria das vezes, se naturaliza.

A voz de mulher que segue problematiza, desautoriza e desconstrói o conceito androcêntrico e militarizado de guerra e de força como constitutivos do homem, face à morte: "Eh, mana, os homens só enterram os mortos quando estão de barriga cheia. Naquele tempo de fome, nós as mulheres é que fazíamos as covas e enterrávamos os mortos" (Kasembe; Chiziane, 2008, p. 153).

Feito isso, a mesma voz olha a vida perspectivando a paz, como se tivesse purgado o trauma, vingado o gênero e perdoado: “[...] Já estou bem com o meu marido, já nos casámos e nos entendemos bem. Os filhos estudam sem problemas. A paz é mesmo coisa boa, o que conta é só ter emprego" (Ibid., p. 153-154). E o amor pode, quem sabe, resumir-se a: 'já nos casámos e nos entendemos bem.

\section{O SUJEITO AMOROSO LIBERTADO: NARRATIVAS DE ALGUMA SUPERAÇÃO DAS MULHERES ANGOLANAS}

A libertação nacional foi o sonho pelo qual a sociedade angolana lutou por cerca de quarenta anos. Durante este tempo histórico homens e mulheres sacrificaram suas vidas, fizeram a revolução pela paz e pela soberania do povo. A revolução, no entanto, nem sempre caminhou conjugada à superação das diferenças de raça, de ideologias e de gênero. O horror da guerra penalizou a sociedade angolana como um todo, sujeitando-a à influência de interesses externos e internos afeitos ao colonialismo, ao capitalismo, ao racismo e ao patriarcado.

A guerra, por ser de caráter militarizado e androcêntrico, penaliza as mulheres escravizando-as e usando-as como 'armas de guerra', conforme já referi. Ao incluí-las na parceria da guerra como militares, usando a metáfora de 'mães da revolução', o faz parcial e tendenciosamente. De maneira que a revolução e a libertação são muito custosas às mulheres, tenham ou não elas os mesmos ideais que os homens. A libertação, para as mulheres, passa pela superação de outras instâncias que vão além daquelas 
almejadas pelos homens, de caráter político, econômico, social, cultural, com vistas à soberania nacional e à autonomia dos povos. A revolução cidadã que as mulheres desejam e pela qual lutaram deveria superar todas as diferenças sociais e de gênero.

Superar a guerra representa objetivar a paz, como externaram as testemunhas de 'O livro da paz'; significa ascender à paz feminista, aquela que conceitualmente excede à visão macro de ausência de guerra, e contempla aspectos microssociais do cotidiano, da ordem da paz interior e da subjetividade. As mulheres de Angola pontuaram essas questões, em suas memórias, sem precisão teórica, mas com sabedoria.

Das histórias de vida delas, passo a examinar, neste tópico, índices de superação da ordem do gênero, 'traços' - reportando a Ricoeur (2007) - de libertação social e amorosa; testemunhos da revolução silenciosa e invisibilizada que fizeram as mulheres angolanas em suas vidas privadas; pequenas conquistas, pequenas libertações trazidas à visibilidade e ao reconhecimento, através da publicação do livro objeto deste estudo.

Não sem antes ratificar a consciência sobre a complexidade do tema amoroso e a diversidade da igualmente complexa cultura angolana. Indagada, em entrevista, sobre a importância da categoria do amor para entender as relações na África, Jennifer Cole (apud Bhana, 2013a, p. 100, tradução minha) respondeu que "o amor é uma categoria deslizante. Conceitualmente, é importante estar atento a conceitos locais, práticas e sua transformação histórica através do tempo mais do que assumir/achar que sabemos o que eles significam, denominando-os de amor". ${ }^{12}$ Essa reflexão serve para baixar ou relativizar a expectativa euro-ocidental que possa, indevidamente, estar permeando a análise.

Dos índices de superação testemunhados, a autonomia econômica é um deles; traço de autoestima, de orgulho e de independência, como se pode ver, no testemunho abaixo, transcrito do livro em questão.

Comecei os meus negócios, construindo dois fornos de lenha. Fazia pastéis no fogareiro e bolinhos no forno que vendia nas cantinas das escolas. Mesmo quando me refugiei no Sumbe, por causa da guerra, sobrevivi graças à pastelaria e costura. Sou estilista, comerciante, tenho um salão de cabeleireiro e um bar. No meu atelier, tive, no ano passado, 36 alunos. Tenho uma casa de modas e aspiro abrir um ciber-café. (Kasembe; Chiziane, 2008, p. 79).

As autorreferências incluem as mais diversas profissões, incluindo o acesso à educação formal:

Sou kinguila. ${ }^{13}$ É bom contar dinheiro. Conhecer os câmbios. Informar-me sempre quando o câmbio sobe e quando desce. Não se ganha muito nesse negócio, mas dá [...] O meu marido é que não está satisfeito com o meu negócio e tem razão: teme pela minha segurança. Neste negócio sofremos 
assaltos; violência. [...] Sou estudante universitária, foi para poder pagar as propinas que decidi arriscar e entrar neste negócio. (Ibid., p. 144).

Há quem tenha a parceria do marido em sua bem-sucedida profissão, o que representa também um ganho:

Nascida numa família pobre, cedo aprendi que a mulher tem que lutar para sobreviver. Sou empresária na área da hotelaria. Eu e o meu marido ajudamo-nos muito. Quando nos casamos, ele tinha uma pequena barraca neste lugar. Eu, que entendia de cozinha, enquadrei no negócio que o marido já tinha com muita facilidade. (Ibid., p. 145).

Os testemunhos referem também lideranças e envolvimento em causas sociais, exemplarmente elucidado no que segue: "Actualmente sou a Vice-Presidente da área técnica da Fitoterapia, onde já participei como formadora, há alguns anos. Também sou Presidente da Associação das Parteiras na Comunidade" (Ibid., p. 166).

Juntamente com índices de representação identitária, é possível depreender traços de consciência cidadã, de direitos e deveres, como sugere a voz transcrita a seguir.

Sou chefe de uma organização feminina, aqui na minha área. As mulheres daqui me respeitam muito. [...] As mulheres têm de ser mais corajosas. Nós devemos respeitar os homens assim como eles nos devem respeito. Sempre que se sentirem injustiçadas, não devem calar porque cada um de nós, homem ou mulher, tem direito à justiça. (Ibid., p. 161).

Há leituras de reconhecimento da transformação social, seguidas de reivindicações da ordem do gênero:

Se nos anos passados, a mulher ficou retida na área restrita do lar, da geração e da criação dos filhos, no trabalho de campo para a subsistência da família, hoje, outras portas terão que lhe ser abertas, para que, ao lado do homem, ela possa realizar-se com igualdade de direitos e competências. (Ibid., p. 88).

O relato que segue é exemplar de enfrentamento de gênero, tomada de posição de certo modo transgressora, trazida da memória, fazendo valer a vontade feminina ao optar pela vida militar: "Hoje sou militar. [...] Sou casada, tenho um filho. Sou uma mulher muito feliz. Quando anunciei ao meu marido que iria fazer o curso militar, quase destruí o meu casamento. O meu marido disse não, mas eu parti” (Ibid., p. 117).

No geral, nota-se na voz dessas mulheres determinação, coragem e empoderamento, resgatados de suas memórias. 
Os fragmentos de testemunhos analisados elucidam que há traços de superação nas memórias, espécie de libertação de caráter pessoal da ordem da independência econômica, subjetiva e amorosa. Traços de empoderamento, de consciência de direitos, comprometimento com causas comunitárias e sociais que resultam em perspectivas mais favoráveis de vida. Uma autonomia restrita a um pequeno universo de mulheres, é bem verdade, mas que poderá multiplicar-se.

Conforme atesta Margarida Paredes (2014, p. 20), "Existe em Angola um terreno de negociação social muito produtivo e inovador, com as mulheres exigindo mais direitos, e um desejo de empoderamento a conquistar terreno".

Como ganho pessoal e social, esse movimento é muito positivo; faz pensar em libertação do corpo amoroso, visando reverter a discriminatória ordem de gênero para viver um amor mais justo e sereno, na perspectiva da paz.

\section{REFERÊNCIAS BIBLIOGRÁFICAS}

AGAMBEN, Giorgio. Homo sacer: o poder soberano e a vida nua. Belo Horizonte: EdUFMG, 2002.

Estado de exceção. São Paulo: Boitempo, 2004.

. O que resta de Auschwitz: o arquivo e a testemunha. São Paulo: Boitempo, 2008.

BHANA, Deevia. How to talk about love in Africa: a view from Jennifer Cole. Agenda Journal: Empowering Women for Gender Equity. p. 99-104, 27 fev. 2013a.

. Introducing love: gender, sexuality and power. Agenda Journal: Empowering Women for Gender Equity. p. 3-11, 27 fev. 2013b.

KASEMBE, Dya. Cartas para maridos temerários. Luanda, Angola: Nzila, 2007.

. As mulheres honradas e insubmissas de Angola. 2o ed. revista. Luanda: Mayamba, 2011.

; CHIZIANE, Paulina (Org.). O livro da paz da mulher angolana: as heroínas sem nome. Luanda, Angola: Nzila, 2008.

MAKA ANGOLA. Disponível em: <http://makaangola.org/maka-antigo/2013/03/09/radio-maka-kinguilas-no-mercado-dos-congolenses/>. Acesso em: 13 nov. 2014.

McCLINTOCK, Anne. Couro imperial: raça, gênero e sexualidade no embate colonial. Campinas, SP: EdUnicamp, 2010.

MELO, Rosa Maria Amélia João. De menina a mulher: iniciação feminina entre os Handa no sul de Angola. Lisboa: Ela por Ela, 2005. 261 p. 
. Homem é homem, mulher é sapo: gênero e identidade entre os Handa no sul de Angola. Lisboa: Colibri, 2007.

. A morte, os defuntos, e os rituais de 'limpeza' no pós-guerra angolano: quais os caminhos para pôr termo ao luto? Afro-Ásia. v. 37, p. 175-200, 2008.

MOURA, Tatiana. Entre Atenas e Esparta: mulheres, paz e conflitos armados. Coimbra: Quarteto, 2005a.

. Novíssimas guerras, novíssimas pazes: desafios conceptuais e políticos. Revista Crítica de Ciências Sociais. v. 71, p. 77-96, jun. 2005 b.

. Novíssimas guerras: espaços, identidades e espirais da violência armada. Coimbra: CES/Almedina, 2010.

; GARRAIO, Júlia; ROQUE, Sílvia. Mulheres e guerras: representações e estratégias. Revista Crítica de Ciências Sociais. no 96, p. 5-8, mar. 2012.

; SANTOS, Rita. Transformar o luto em luta: sobreviventes da violência armada. Oficina do CES. Universidade de Coimbra, Portugal, no 307, p. 1-30, maio 2008.

PAREDES, Margarida Isabel Botelho Falcão. Deolinda Rodrigues, da familia metodista à familia MPLA, o papel da cultura na política. Caderno de Estudos Africanos. ISCTE, Lisboa, no 20, p. 11-26, 2011.

Mulheres na luta armada em Angola: memória, cultura e emancipação. 353 p. Tese (Doutorado em Antropologia) - Instituto Universitário de Lisboa, Lisboa, 2014. Não publicada.

. El testimonio de Rita André Tomás, "Memórias da luta de libertação" em Angola. Revista Mulheres e Literatura. v. 14, 2015. Disponível em: <http://litcult.net/site/category/mulheresrev/revista-mulheres-e-literatura-vol-14-2015>. Acesso em: 22 fev. 2015.

RICOEUR, Paul. A memória, a história, o esquecimento. Campinas, SP: Ed.Unicamp, 2007.

Recebido para publicação em 06/10/2016

Aprovado em 02/03/2017

\section{NOTAS}

1 Doutora em Literatura pela Universidade Federal de Santa Catarina (UFSC), com doutorado-sanduíche no CES da Universidade de Coimbra, PT. É professora do Centro Universitário de Brusque (Unifebe), onde se dedica ao ensino de Literatura.

2 As mulheres entrevistadas pertenceram aos dois lados da Guerra Civil, e não há identificação a qual lado da guerra as memórias pertencem.

3 A APN, ONG responsável pela desminagem de uma parte do território nacional angolano, tem um programa para promover a participação da mulher na vida pública e política, em Angola. 
4 Alguns provérbios e um adágio popular não trazem referência. Dois deles referem a Colectânea de provérbios e contos de Serafim Quintinto (Kasembe; Chiziane, 2008, p. 17-81).

5 KASEMBE, Dya; CHIZIANE, Paulina (Org.). O livro da paz da mulher angolana: as heroínas sem nome. Luanda, Angola: Nzila, 2008. p. 91.

6 Citação no original: "Historically, Africa has been marked as a place where love either didn't exist (hence missionary discourse about the slave trade) or was made impossible because of political and economic conditions" (Cole apud Bhana, 2013a, p. 100).

7 Margarida Paredes (2014, p. 205) refere que "Na Luta de Libertação as mulheres aparecem representadas num papel simbólico. Uma das fotografias mais divulgadas durante a guerra nacionalista apresenta uma mulher com uma arma a tiracolo e uma criança no colo. A arma e a criança representam o quadro ideológico no qual as mulheres da OMA eram percepcionadas no espaço público durante a guerrilha, as 'mães da revolução' e as 'camaradas de armas' que combateram ao lado dos homens, uma representação ambivalente que ligava a maternidade à guerrilha e ao militarismo como se fossem complementares".

8 “O termo 'nação' deriva de natio: nascer. Falamos das nações como 'mãe pátria ou solo 'pátrio'. Os estrangeiros 'adotam' países diferentes dos seus e se naturalizam na 'família’ nacional. Falamos da 'Família das Nações', da 'terra natal' e de 'terras nativas.' (McClintock, 2010, p. 523).

9 "Consumi a minha vida de armas na mão, ao lado dos homens, mas o meu esforço não foi reconhecido. Muitos colegas menos competentes do que eu, foram promovidos e patenteados só por serem homens e hoje vivem bem. [...] A discriminação existe em todo o lado, mas é no exército que se faz sentir com maior intensidade. $\mathrm{O}$ mundo das armas foi sempre o santuário dos homens." (Kasembe; Chiziane, 2008, p. 111-112). "Nas negociações de paz, nós mulheres combatentes fomos esquecidas. Quando registraram os desmobilizados escreveram apenas os homens. Nós mulheres fomos completamente excluídas nesse processo e, para agravar as coisas, nas negociações de paz não havia mulheres. Nós fomos afastadas. [...] fomos incluídas nos grupos sociais das mulheres vulneráveis" (Ibid., p. 140).

10 “[...] as mulheres e crianças (consideradas desprotegidas, as mais débeis) constituem colectivos particularmente afectados" na guerra (Moura, 2005a, p. 57). Instituições sociais, como a família, têm sido alvos de guerra, a "violação é utilizada como acto de humilhação contra as mulheres e contra os homens seus familiares" (Ibid., p. 57).

11 Testemunho repetido neste subitem pela força de seu significado.

12 Citação no original: “[...] love is a slippery category. Conceptually, it is important to attend to local concepts, practices and their historical transformation over time rather than assume we know what those attachments are by already labelling them as love" (Cole apud Bhana, 2013a, p. 100-101).

13 “A expressão kinguila, que em Kimbundo designa 'alguém que está a espera de algo', tornou-se sinónimo na capital angolana de câmbio de rua, quando desde o final dos anos 80 começaram a aparecer nas ruas da cidade pessoas (sobretudo mulheres) envolvidas na troca de dólares por kwanzas (e vice-versa)." (Maka Angola, [s./d.]). 